\title{
De-motivators of Employees in the Public Sector in Arua District, Uganda
}

\author{
Hardson Kwandayi (Corresponding Author) \\ Program Director, Public sector management Training Program, Africa University \\ P. O. BOX 1320, Mutare, Zimbabwe \\ E-mail: hkwandayi@gmail.com
}

Nelson Jagero

Director of Distance Education, Africa University, Mutare, Zimbabwe

E-mail: jageronelson@yahoo.com

Jimmy Matata

Senior Assistant Secretary, Arua District, Uganda

E-mail: matatajimmy@yahoo.com

Received: August 9, 2013 Accepted: September 4, 2013 Published: November 21, 2013

doi:10.5296/bmh.v1i2.4596 URL: http://dx.doi.org/10.5296/bmh.v1i2.4596

\begin{abstract}
De-motivation of the public sector employees is a key aspect in Public Administration as far as human resources management is concerned. It is argued that people are without a doubt the most valuable resource to any organization. It is upon this ground that this study sought to assess the factors that de-motivated staff in the public sector of Uganda, specifically Arua District Local Government. In this study, 15 district staff (Heads of departments and office assistants), 30 sub county staff (Community Development Officers, Sub County Chiefs, Accounts Assistants and Extension staff) were used as the research subjects. Self-administered questionnaires were used as research instruments. The priority de-motivators were lack of autonomy and variety, low salary, organizational politics, unending clients' demands and ineffective communication. The study recommends that, the
\end{abstract}


government should initiate low cost housing schemes including soft loans for the public sector employees. In addition, official residences should be built for the staff at their work stations, this specifically would apply to the Sub County staff who would need to endure residing near their work places and this scheme would most likely contribute to the conduciveness of work environment.

Keywords: de-motivation, public administration, employees, Arua district 


\section{Introduction}

During the 2005/06 National assessment many districts were penalized for not meeting the minimum conditions for assessment and this included Arua District Local Government as well. Arua district used to be one of the performing areas in service delivery, for that matter it had always been a role model in the late 1990s up to around 2004. This fact was attributed to a de-motivated nature of the human resource in the public sector in the country where promotions are almost a dream. The locals used to benefit from better service delivery. The civil servants were active at least the majority if not all of them. But all the good services have deteriorated. This was despite the fact that Arua District service commission (DSC) embarked on recruiting new staff and qualified ones for that matter. The district also implemented the government policy of restructuring and various reforms but this seems to have not solved any of the challenges of service delivery. However, despite the existence of these sound government policies of public sector reform, delivery of service has not been effective as intended.

Whereas several studies have been conducted to assess the factors that affect service delivery in Uganda, these in most cases do not address the local Governments. The question this study sought to answer was: What de-motivates staff of public sector of Uganda?

\section{Objective of the Study}

To explore the factors that demotivate employees of public sector to perform their duties and responsibilities.

\section{Literature Review}

According to Johansson, et al (2009) important as identifying what an employee wants, is knowing what employees don't want. Avoiding de-motivators is another key to staff retention. Different aspects of the job will attract different employees, but de-motivators will be around long after an employee has chosen a job. (Spitzer, 1995) These obstacles to blissful employment can take on a number of forms. Politics and unclear expectations are two problems that organizations face. Additionally, according to him, other problems that have a negative effect are constant change, low quality standards, and unproductive meetings. The first step to eliminating these moral busters is to obtain employee feedback to identify consistent themes.

Employees tend to appreciate these collaborative efforts as they are viewed as tangible efforts to improve the quality of the work environment. Employers who assume that they know what the problems are relying on their own perspective and fail to see the issue through the eyes of their employees.

According to Karen (1996) Leading de-motivators are: office politics (surprise) that send unclear and anxiety-provoking messages; unclear expectations-when everything is labeled "a priority"; hypocrisy — when the manager says, "We trust you," but an employee knows he can't do anything without first getting permission; being taken for granted--receiving little or no positive feedback or recognition; and being forced to do poor-quality work. In addition, 
lack of material and equipments, difficult living conditions, subjective performance appraisal, partner living far away are some of the de-motivating factors. (Dieleman, M., Toonen, J., Touré, H., \& Martineau, T., 2006)

According to Johannson, et al. (2009), the most common and noticed de-motivators according to previous research done among employees are:

Organizational politics-Involves competition for power, influence, favors, and scarce promotions (Nollen, 1996).

Unclear expectations of the employee-When there is inconsistency between what is said and what is done, together with mixed messages being transmitted throughout an organization, employees tend to express frustration (Spitzer, 1995).

Public service employees are dogged with a number of expectations from both employer and the public they serve. Accordingly, Williams, (in Maidment, 2000) explains that "Some leaders build high productivity expectations into the value systems of their organizational cultures. They expect a high sense of responsibility, high productivity, and high quality of output from their employees." Employees who do not fulfill those expectations soon find occasion to seek work elsewhere or be transferred to a new station for the case of public sector.

Lack of autonomy and variety-When employees are not allowed to work autonomously with a variety of tasks that suit their capability, the work tends to be perceived as tedious and unsatisfying (Hunt, 1994). According to him, one of the most frequently mentioned causes of satisfaction, or subsequently dissatisfaction, is being able to work autonomously and with a varied range of activities. He further elaborates on the issue of variety and refers it to "the range of skills required, the range of problems confronted, and the range of products, clients industries served". Without being able to work autonomously, he further argues, it is not possible for the employee to pursue the varied tasks that the job offers

Clients' demands-The clients can be an important source of de-motivation if they for example demand more work than what was originally stated, or change projects without explaining how it will affect the worker (Hunt, 1994).

Communication-Decisions which will somehow affect the employees are constantly made. If these decisions and the implications of them are not clearly explained to the employees, people start questioning and accusing management, and de-motivation is bound to arise (Gupta-Sunderji, 2004).

Goals-When goals are not conveyed clearly enough, employees can start to question what is expected of them, making them de-motivated to carry out their tasks (Gupta-Sunderji, 2004).

Salary-Kessler (2000) suggests that a fundamental source of de-motivation arrives from employee's perception of them being wrongly rewarded in monetary terms.

Powerlessness-Refers to the employee's ability to exhibit power over something or someone, and the ability to affect one's own situation (Hunt, 1994). 
Belongingness - Is referred to as "the feeling of not belonging" and "the engagement to the company”, also known as organizational commitment (Jungqvist \& Tagesson, 2009)

Performance appreciation- Appreciation is a critical basic human need that includes a special notice or acknowledgement for the person's accomplishment (Hansen, Smith, \& Hansen, 2002).

\section{Methodology}

\subsection{Research Design}

This study employed descriptive research designs through a combination of qualitative and quantitative methods. This will help to describe the phenomenon and draw inferences against the theoretical framework. This will also provide comparable response which will facilitate the coding and analysis process.

\subsection{Population of the Study}

In this particular study, the population was the civil servants in various departments at the District level including the heads of departments, accounts staff, office assistants (Secretaries and Messengers) and audit staff. While those from the Sub counties consisted of the Sub County chiefs as the accounting Officers at that level, Community Development Officers (CDOs), Accounts Assistants and Extension staff (Sub County NAADS Coordinators) and Health Assistants in Arua District. The choice of these population categories was because of their significant positions in the public sector and most importantly as public service delivery points of the Government of Uganda (GOU). The researcher was cognizant of the fact that both male and female employees of the district participated in this study.

\subsection{Sampling Procedure}

In this study, simple random sampling was used to select the representative number of employees for the study, stratified random sampling was used to get a fair representation of all the categories of respondents and owing to the sparseness of most of the respondents geographically. Cluster sampling was used for the different departments of the district and the sub counties being many, to give a fair representation and every respondent had a chance of being selected. In this case each of the 25 sub counties had a chance of being selected in the strata. However, the Counties will be purposefully selected since there are only four in the whole district. The researcher was cognizant of the rural and urban locations to have a fair response and draw some inferential as experiences and feelings differed.

Owing to the time limit and distance to the data collection point, Self-administered questionnaires relating to the motivation factors (both intrinsic and extrinsic) and de-motivation factors were designed where respondents completed and returned to the researcher through the research assistant. This eliminated interviewer and the respondents' bias.

\subsection{Population and Sample}

A total of 45 respondents out of the population of 132 were randomly sampled to come up 
with a representative data that cut across all the categories of the respondents in Arua District in general.

Due to the large number of employees in the whole district, the study took a sample from a total number of 132 staff at various levels and positions mentioned above that according to the researcher were literate and knowledgeable to answer the questionnaires.

\subsection{Instruments}

The research used one method of data collection and that was the questionnaires. Perception of the employees were captured on a Likert-scale (Strongly disagree, Disagree, Undecided, Agree and Strongly Agree) for de-motivation factors and Job Satisfaction Survey (JSS).

\section{Data Presentation, Analysis and Discussion}

\subsection{Rating of De-Motivators}

Table 1 shows the findings of the rating of responses about the common de-motivators in order to get the feeling that the respondents had.

Table 1. Rating of de-motivation factors of employees in the public sector

\begin{tabular}{|c|c|c|c|c|c|c|c|}
\hline $\begin{array}{l}\text { De-motivation } \\
\text { Factors }\end{array}$ & Factor Questions & SD & $\mathbf{D}$ & UD & A & SA & $\begin{array}{l}\text { Total } \\
\%\end{array}$ \\
\hline $\begin{array}{l}\text { Organizational } \\
\text { Politics }\end{array}$ & $\begin{array}{l}\text { There is too much bickering and fighting at } \\
\text { work. }\end{array}$ & 7.9 & 10.5 & 15.8 & 18.4 & 47.4 & 100.0 \\
\hline $\begin{array}{l}\text { Unclear } \\
\text { expectations }\end{array}$ & Work assignments are not fully explained. & 5.3 & 31.6 & 15.8 & 36.8 & 10.5 & 100.0 \\
\hline $\begin{array}{l}\text { Autonomy \& } \\
\text { Variety }\end{array}$ & $\begin{array}{l}\text { Many of our rules and procedures make doing } \\
\text { a good job difficult. }\end{array}$ & 2.6 & 5.3 & 7.9 & 50.0 & 34.2 & 100.0 \\
\hline Client's demands & $\begin{array}{l}\text { I have too much to do at work. I will not be } \\
\text { able to satisfy the conflicting demands of } \\
\text { various people from me }\end{array}$ & & 15.8 & & 71.1 & 13.2 & 100.0 \\
\hline $\begin{array}{l}\text { Lack of } \\
\text { Communication }\end{array}$ & $\begin{array}{l}\text { I often feel that I do not know what is going on } \\
\text { with the organization. }\end{array}$ & 5.3 & 21.1 & 5.3 & 52.6 & 15.8 & 100.0 \\
\hline Goals Unclear & $\begin{array}{l}\text { The goals of this organization are not clear to } \\
\text { me. }\end{array}$ & 7.9 & 50.0 & 7.9 & 31.6 & 2.6 & 100.0 \\
\hline Low Salary (pay) & $\begin{array}{l}\text { I feel unappreciated by the organization when } \\
\text { I think about what they pay me. }\end{array}$ & & 13.2 & 5.3 & 50.0 & 31.6 & 100.0 \\
\hline Belongingness & I sometimes feel my job is meaningless. & 5.3 & 42.1 & & 31.6 & 21.1 & 100.0 \\
\hline $\begin{array}{l}\text { Not appreciating } \\
\text { Performance }\end{array}$ & I do not feel that the work I do is appreciated. & 10.5 & 52.6 & 13.2 & 21.1 & 2.6 & 100.0 \\
\hline
\end{tabular}




\section{Ml Macrothink}

Business and Management Horizons

ISSN 2326-0297

2013, Vol. 1, No. 2

Most of the respondents at $47.4 \%$ strongly agreed that there was too much bickering and fighting at work to which $7.9 \%$ strongly disagreed. The findings also revealed that a fairly large percentage, 36.8\% agreed that work assignments were not fully explained, this almost equaled the $31.6 \%$ respondents who disagreed, and this result could be due to communication failures or incompetence of some supervisors and employees recruited in the public sector.

Fifty percent of the respondents agreed that many of their rules and procedures made doing a good job difficult, as $34.2 \%$ agreed strongly to this, the a smaller percentage of 5.3 disagreed. The researcher finds this not so surprising and suggests that, it could be due to the system of operation that the public service uses where there might be a lot of processes and bureaucratic tendencies thus the result of the findings.

Majority $71.1 \%$ of the respondents agreed to the fact that they had too much to do at work. And contented that they would not be able to satisfy the conflicting demands of various people from them, $13.2 \%$ strongly agreed and the paltry $15.8 \%$ disagreed.

A reasonable percentage (52.6) of the respondents agreed that they often felt that they did not know what was going on with the organization and this was in contrast to $21.1 \%$ who disagreed. This most likely communication issue was confirmed by $31.6 \%$ of the respondents who agreed that the goals of the organization were not clear to them; much as fifty percent of the respondents disagreed the goals of the organization were not clear to them.

When asked whether they felt unappreciated by the organization when they think about what they are paid, $50 \%$ of the respondents agreed and 31.6\% strongly agreed with a little percentage that disagreed. On the other hand a fairly large percentage disagreed that sometimes they felt their job was meaningless. It should also be noted that, $52.6 \%$ of the respondents disagreed that they did not feel that the work they did was appreciated, on the contrary, $21.1 \%$ agreed.

\subsection{Ranking of the Factors of Motivation and De-Motivation of Public Sector Employees}

Table 2. Ranking of motivators

\begin{tabular}{llll}
\hline Motivation Factor & Total Score & Average Total Score & Factor Rank \\
\hline Supervision & 654 & 130.8 & 1 \\
Nature of Work & 482 & 120.5 & 2 \\
Coworkers & 475 & 118.8 & 3 \\
Communication & 430 & 107.5 & 4 \\
Contingent Rewards & 352 & 88 & 5 \\
Working Environment & 404 & 80.8 & 6 \\
Pay & 318 & 79.5 & 7 \\
Operating procedures & 146 & 73 & 8 \\
Promotion & 283 & 70.8 & 9 \\
\hline
\end{tabular}




\section{Macrothink}

Business and Management Horizons

ISSN 2326-0297

2013, Vol. 1, No. 2

This ranking was done using the Job Satisfaction Survey (JSS) administered severally Spector, (1997). The tools were minimally moderated to suit this study where the negatively worded items were reverse scored. Below are the reversals for the original item score in the left column and reversed item score in the right. The rightmost values were substituted for the leftmost.

$1=5$

$2=4$

$3=3$

$4=2$

$5=1$

The negatively worded items were 2,4,6,8,10,12,14,15,16,18,19,21,23,24,26,29,31,32,34,36. Meanwhile the positively worded items were $1,3,5,7,9,11,13,17,20,22,25,27,28,30,33,35$ on the questionnaire. The scores were then added to for each factor of motivation so as to determine the ranks of each as the respondents had posted. The above table therefore represents the ranking of the motivation factors for employees of ADLG. Because not all factors had the same number of items, the average of the totals was divided by the total number of the items of a factor. This then fairly balanced the scores as the averaged scores were then used to determine the ranks of the factors.

According to the table 2 above, supervision, nature of work, the kind of coworkers the respondents had, effective communication and contingent reward were the five top most motivators of the employees of the public sector of Arua District and therefore, the administration needs to take a lot of interest to consolidate the motivators to achieve the best out of the employees. However, working environment, operating procedures, pay and promotion ranked among the last but care has to be taken to equally address them though not much energy should be wasted on them. For the entire ranking results see the appendices.

Table 3. Ranking of de-motivators

\begin{tabular}{lll}
\hline De-motivation factor & Score & Rank \\
\hline Lack of autonomy \& variety & 155 & 1 \\
Low Salary (Pay) & 153 & 2 \\
Organizational Politics & 147 & 3 \\
Clients' Demands & 145 & 4 \\
Lack of Communication & 133 & 5 \\
Lack of Belongingness & 122 & 6 \\
Unclear expectations & 118 & 7 \\
Goals Unclear & 103 & 8 \\
Lack of Performance Appreciation & 96 & 9 \\
\hline
\end{tabular}


Unlike the motivators, de-motivators had one item each to score against and they were scored positively irrespective of the framing of the question. However, in totality, the items were all negative in nature hence there was no need for negatively scoring them. The ultimate total score from the responses of the respondents were what is reflected on the table above. Having that at the back of the mind, the table 3 above shows that autonomy and variety, low salary (pay), oraganizational politics, clients' demands and lack of communication were the five top most priority de-motivators of the respondents.

Therefore the district should give much attention to address these de-motivators in order for the employees to substantially perform their duties. However, the findings indicated that lack of belongingness, unclear expectations, unclear goals, and lack of performance appreciation were not key priority motivators but still important to take not of but not burn a lot of energy on because for instance the respondents are more or less unanimous in their views that unclear expectations are not a big de-motivator for them in their work settings. It would appear that expectations about them and what they are to accomplish is clearly conveyed to them as attested by $31.6 \%$ of the respondents who disagreed that work assignments were not fully explained to them or they are not interested about what is expected of them due to the fact that they are probably the heads of department or accounting officers and supervisors for the case of sub county chiefs, and thus they simply accept what their immediate supervisors say. The figure below shows the ranking by scores of the de-motivators.

\section{Conclusion}

The most prominent top five de-motivators were lack of autonomy and variety, low salary, organizational politics, clients' demands, and lack of effective communication. Whilst this were most important according to the researcher and based on the findings, the other de-motivators should not be discarded but more effort should be put to address all of them but may not be possible to do at a go, hence the reason for the top most five.

Therefore, central government, local government and individual interventions to address the deficiencies in the top five most employee motivators are indispensable if the service delivery to the public is to be improved and at the same time a lot of efforts be put to address the main de-motivators. The researcher concludes that motivation of individuals keep changing form and from place to place hence not static. This calls for the managers and government institutions to perform job satisfaction surveys very often to ascertain their employees' level of motivation and de-motivation so as to achieve the highest potential of their employees.

\section{Recommendations}

The researcher recommends that, the government in a bid to address the challenges at work environment that de-motivate the employees should help the local governments to construct low cost housing and at the same time provide or negotiate with commercial banks soft housing loans to the employees so that they get reinvigorated to perform their duties. This would be an extra addition to the already available other fringe benefits that the employees are entitled to. The researcher believes that when the employees have their own houses besides the ones constructed by government at their work places, their families would be 
comfortable as the employees get to their work places hence a motivation.

their efforts on consolidating the motivators of the employees that were priority while devoting less of their time on the others. It must be recognized here that the other factors indirectly affect the motivation levels of the employees as well. For the de-motivators, the researcher equally suggests that more efforts be concentrated to addressing the priority de-motivators. That is, lack of autonomy and variety, low salary, organizational politics, clients' demands, and lack of effective communication. However, this does not mean leaving out the rest of the de-motivators.

\section{References}

Dieleman, M., Toonen, J., Touré, H., \& Martineau, T. (2006). The match between motivation and performance management of health sector workers in Mali. Retrieved from http://www.human-resources-health.com/content/4/1/2

Gupta-Sunderji, M. (2004). Employee Retention and Turnover: The real reason employees Stay or Go. FMI Journal, 15(2), 37-48.

Hansen, F., Smith, M., \& Hansen, R. B. (2002). Rewards and recognition in employee motivation. Compensation Benefits Review, 34, 64-72.

Hunt, J. (1994). The European consultant: What motivates and what de-motivates? Business strategy review, 5, 15-28.

Johansson, S., Müller, P., \& Vestin, K. (2009). De-motivators among Temporary Agency Workers in the Industrial Sector: A case study of Proffice AB in Jönköping. Jonkoping University.

Kalala, S. T. (2009). Employee motivation rewards from salary to gratuitous. Toronto: NPPC. Retrieved

from http://en.articlesgratuits.com/employee-motivation-rewards-from-salary-to-gratuitous-id5206. php

Maidment, F. H. (2000). Organizational Behaviour. Connecticut: McGraw-Hill. Retrieved from http://www.dushkin.com/annualeditions/

Nollen, S. (1996). Negative Aspects of Temporary Employment. Journal of Labour Research, 17(4), 567-582.

Spreitzer, G. M. (1995). Psychological empowerment in the workplace: dimensions, measurement, and validation. Carlifornia: Academy of Management Journal, 38, 1442-1465.

\section{Copyright Disclaimer}

Copyright reserved by the author(s).

This article is an open-access article distributed under the terms and conditions of the Creative Commons Attribution license (http://creativecommons.org/licenses/by/3.0/). 